\title{
Images of Chalices in Transylvanian Panel Paintings
}

\section{AdRIAN STOIA}

The study of the items illustrated on mural and panel painting, in connection with still existing items, can document medieval material culture. The representation of chalices on almost half of such paintings from Transylvania is a proof of its important symbolist value in religious rituals. These representations also certify the high level of the goldsmiths' art from Transylvania. The present study is intended both as a repertory and an analysis of these sacral objects illustrated in mural and panel paintings.

Keywords: Chalice, altarpiece, painting, Transylvania

The fortified churches in Transylvania were a favorite subject of the Saxon historiography. Their mural or panel paintings were studied in the $19^{\text {th }}$, but especially in the $20^{\text {th }}$ century. Panel paintings were generally ordered by parochial priests supported by local communities to honor the patron saints or they came as donations/gifts from patricians or rich noblemen. Today only a small amount of painted ensembles from the $15^{\text {th }}$ and $16^{\text {th }}$ century have survived in Transylvania, most of them disappearing after adoption of the Reformation (among these seemingly the most valuable ${ }^{1}$ ).

Itinerant craftsman or those settled in Transylvania in local artistic workshops disseminated and developed in this frontier territory a provincial art with a specific style, but stylistically oriented towards Central Europe, in the territory of present-day Austria and Southern Germany. According to the latest studies, there were approximately one hundred painters in Transylvania during the $15^{\text {th }}$ and $16^{\text {th }}$ centuries. ${ }^{2}$

Besides painting workshops, other workshops appeared as well to satisfy local service necessities, such as sculpture or goldsmiths workshops, early gothic silver work being a product of the latter.

The cults' art designs reached their highest peaks during the $15^{\text {th }}-16^{\text {th }}$ centuries, stagnating after this period under the influence of Reformation, during which the influence of image radically changed. ${ }^{3}$ Items which have

\footnotetext{
* Adrian Stoia, PhD student at the Faculty of History and Patrimony, Lucian Blaga University of Sibiu. Contact details: Str. Primăverii 12, Sibiu; e-mail: adistoia@yahoo.com.

${ }^{1}$ Virgil Vătășianu, Istoria artei feudale în Țările Române, vol. I, București 1959, p. 777.

${ }^{2}$ Ciprian Firea, Arta polipticelor medievale din Transilvania (1250-1550), vol. II, PhD Dissertation (manuscript), Cluj-Napoca, Universitatea Babeş-Bolyai 2010, p. 90.

${ }^{3}$ Andrei Kertesz, in: Thomas Nägler (ed), 800 de ani Biserică a Germanilor din Transilvania, Thaur bei Innsbruck 1991, p. 72.
} 
survived from the second half of the $14^{\text {th }}$ century confirm the activity of local silversmiths $s^{4}$, organized in guilds by the end of the $15^{\text {th }}$ century. The large number of items made show today the development of the taste and of the aesthetic role in decorating sacral space and prove the important function of the image in religious service. Numerous materials and documentary proofs show an intense activity of Transylvanian goldsmiths and silversmiths. From all the objects made by Hermannstadt's (Sibiu's) smiths from the $14^{\text {th }}$ to the $17^{\text {th }}$ century we have today 450 liturgical and laic (jewelry) items. ${ }^{5}$ Most of the works of Sibiu's goldsmiths and silversmiths disappeared in the second half of the $16^{\text {th }}$ Century after the adoption of the Reformation. ${ }^{6}$ They were either melted down for the raw material or sold on different occasions. Those which did survive were hoarded and hidden (like those from the Evangelic church in Cisnădie, Sibiu ${ }^{7}$ ) or they were kept and still used in local churches for sacred service, later being donated to museums for safe keeping. The treasury of liturgical and laical silver in Brukenthal National Museum includes over one thousand items. ${ }^{8}$

Although some of the silver and gold liturgical items used before the Reformation had no use afterward - such as this monstrance, the chrismatory and the reliquary - others like the chalice, the crucifix and the ciborium are still used, their shapes and ornaments wearing the stylistic imprint of the period when they were created. ${ }^{9}$ The most important among these items was

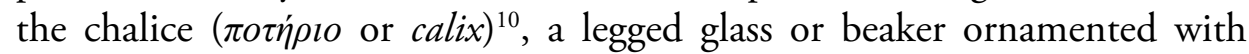
sacred scenes or with geometrical and vegetal motifs. It was usually made out of precious metal and was later inlaid with enamel and precious stones. Used in the sacred service for the Communion of the clerics and the believers who attend the service, ${ }^{11}$ the chalice is together with the paten, one of the most important altar vessels (vasa sacra).

\section{${ }^{4}$ Ibidem.}

${ }^{5}$ Daniela Dâmboiu, "Câteva constatări privind breasla aurarilor din Sibiu”, in: B.A.M., III.2, Sibiu 2008, p. 213.

${ }^{6}$ D. Dâmboiu, Ioan Albu, "Stilistica şi ornamentația argintăriei de cult a saşilor transilvăneni”, in: T. Nägler (ed.), 800 de ani Biserică a Germanilor din Transilvania. Catalogul expoziției, Thaur bei Innsbruck 1991, p. 103.

${ }^{7}$ D. Dâmboiu, Orfevrăria liturgică sibiană. Din tezaurul Muzeului Național Brukenthal, Sibiu 2004, p. 6.

${ }^{8}$ Sabin Adrian Luca (ed.), "Introduction” to: D. Dâmboiu, Breasla aurarilor din Sibiu între secolele XV-XVII, Sibiu 2008, p. 5.

${ }^{9}$ D. Dâmboiu, Orfevrăria liturgică, p. 17.

${ }^{10}$ D. Dâmboiu, Breasla aurarilor, p. 62.

${ }^{11}$ Ene Braniște, Ecaterina Braniște, Dicționar de cunoștințe religioase, Sibiu 2010, p. 344. 
While there are numerous studies concerning these topics, analyzing mural or panel paintings as testimony of the material culture is a relatively new approach. This paper is concerned with the research of the chalices depicted on panel paintings in Transylvania.

We have included in this paper images of the Eucharistic chalice depicted in the altarpieces of Beia (Brașov), Bruiu (Sibiu), Cund (Mureş), Cetăţuia (Harghita), Fişer (Brașov), Hălchiu (Brașov), Tătârlaua (Alba), Leliceni (Harghita), Mălâncrav (Sibiu), Mediaş (Sibiu), Moşna (Sibiu), Sibiu, Şaeş (Mureş), Vlaha (Cluj), Dupuş (Sibiu), Şoroştin (Sibiu) and on a volet from an altarpiece with the image of Saints, on a panel with the representation of The Martyrdom of St Barbara and on a panel with the image of Vir dolorum, the last three currently in the possession of Brukenthal National Museum in Sibiu.

The images of the liturgical vessels (ciborium, monstrance, chalice) on the volets of the altarpieces in Boian, Mălâncrav, Proştea Mare (Târnava, Sibiu) or on the panel with The Martyrdom of St. Barbara is analyzed by the researcher Daniela Dâmboiu. ${ }^{12}$ In the scenes depicted on Transylvanian altarpieces we have identified 22 chalices. The oldest altarpiece of all the ones included in this study is the one devoted to The Virgin from the Evangelic church in Mălâncrav and dated in 1455-1465. ${ }^{13}$ It is also one of the best preserved altarpieces still existing in the church for which it was ordered. In this case we also know the identity of the person who ordered the altarpiece and who also founded the church: the noble family Apafi. The latter altarpieces included in the study date from 1520-1525: Cetățuia, Fişer, Mediaş, Moşna.

The altarpiece from Beia ${ }^{14}$, devoted to St. Ursula, has been kept since 2005 inside the Evangelic church "on the Hill” in Sighişoara (Mureş). The altarpiece is dated in 1513; the year was written on the red frame of the central chest and the altarpiece was hypothetically attributed to "Johannes Stoss" 15 .

The presence of the chalice (plate 1) depicted on the closed altarpiece is in connection with the painting illustrating Prayer on the Mount of Olives. Jesus is depicted in the middle section of the altarpiece, on his knees with his hands held up in prayer. Over his hands, on a yellowish rock there is the image of the chalice. The vessel is painted in a stylised manner and it is shown

\footnotetext{
${ }^{12}$ D. Dâmboiu, "Câteva constatări”, p. 70.

${ }^{13}$ C. Firea, Arta polipticelor medievale, vol. II, p. 210.

${ }^{14}$ V. Vătăsianu, Istoria artei feudale, pp. 793-795.

${ }^{15}$ Ibidem.
} 
with a round bowl with no applied ornamentation and supported by a faced stem and a high lobate foot. On the upper part of the stem a knob with quadrilobe buttons is attached. This item with distinctly Romanesque print shows similarities with the chalice from Cârța ${ }^{16}$, only the bowl is not as high.

The altarpiece devoted to St. Nicolae from the Evangelic church in Bruiu - kept since 2000 in the altar of the church in Cisnădie (Sibiu) - was repainted in 1728, only later through the restoration in 1973-1974 of Gisela Richter, the old painting being brought back to life. ${ }^{17}$ The predella with its 14 helping Saints was also repainted with the scene of The Last Supper. The ichnographical theme of the 14 saints is quite popular in German painting, the depiction of the attributes of the saints making possible their identification. On the right side (facing the altarpiece) of the predella a group of three women martyrs is depicted, the one on the left being St. Barbara. She holds a chalice (plate 2) with a big bowl, with a slightly flanged rim, an indented knob and a faced stem supported by a probably lobate foot. It shows some similarities to the chalice from Roandola. ${ }^{18}$

The altarpiece in Cund (Mureș County) attributed to "Johannes Stoss" from Sighișoara and quartered today in the Evangelic church "on the Hill" in Sighişoara is dated in $1515-1520^{19}$ and devoted to St. Nicolae. Here in the cycle of scenes illustrating The Passion of Christ (on the closed altarpiece), namely in the scene of Prayer on the Mount of Olives, Jesus is painted with his arms up in prayer and with the chalice in front of him on a rock. The lower register of the altarpiece shows the sleeping apostles and behind Jesus a wooden fence is depicted and a gate where Judas and the soldiers of the temple are waiting. The chalice (plate 3 ) has a massive even bowl with a large opening and an almost flat lower part. The bowl stands on a spherical flatted knob, a short conical stem and a foot with a vertical cut. The image of the chalice shows similarities with the chalice from Turnișor $(\mathrm{Sibiu})^{20}$, but the stem is very small in the painted image.

The altarpiece devoted to The Virgin Mary from Cetățuia (Harghita

16 Viktor Roth, Kunstdenkmäler aus den sächsischen Kirchen Siebenbürgens. Goldschmiedearbeiten, Sibiu 1922, pl. 22/1.

${ }_{17}$ Gisela Richter, Otmar Richter, Siebenbürgische Flügelaltäre, Thaur bei Innsbruck 1992, pp. 123-131; Emese Nagy - Sarkadi, Local Workshops - Foreign Connections. Late Medieval Altarpieces from Transylvania, Ostfildern 2012, p. 155.

${ }^{18}$ V. Roth, Kunstdenkmäler, pl. 15/4.

${ }^{19}$ C. Firea, Arta polipticelor medievale, vol. II, p. 125.

${ }^{20}$ V. Roth, Kunstdenkmäler, p. 11, pl. 14. 
county), dated in 1520-1525 21 , has on each of the eight panels of the exterior volets a sainted virgin martyr. On one of the upper panels Saint Barbara is depicted accompanied by her attributes: the tower and the chalice. This well preserved painting depicts the chalice (plate 4) in the hand of the saint having a big even bowl with a slightly flanged polished rim, a conical stem and a circular foot ornamented with vegetal motifs. A possible similarity of this foot might be established to the one of the chalice in Cisnădie ${ }^{22}$, but the bowl which is much larger rather resembles the bowl of the chalice in Lovnic (Brașov County) ${ }^{23}$.

On the altarpiece from Fișer (Brașov County), dated in 1522 (the year was written on the book depicted in the scene Death of St. Martin) ${ }^{24}$, on the Feast-day side the left volet is painted with the image St. Martin Missa, a local adaptation of Albrecht Dürer's stamp The liturgy of St. Grigorie the Great. ${ }^{25}$ On the table of the altar in front of the image of the risen Christ showing the marks of his martyrdom, the holy chalice and floating Host are depicted (plate $5 \mathrm{a})$, the sacramental image of the body and blood of Christ ${ }^{26}$. The colour of the chalice is golden. Its bowl has a strongly flanged rim with a round base. The knob is divided in four spherical buttons fastened to the short stem. The circular foot is ornamented with a vegetal motif climbing up to the knob.

On the same altarpiece from Sighișoara painted by "Johannes Stoss" (tempera on wood), amongst the typical scenes of The Passion of Christ, on the panel with the Prayer on the Mount of Olives we find a second chalice (plate $5 \mathrm{~b}$ ), painted on the work-day side of the altarpiece. Jesus is depicted praying by his sleeping apostles. In front of him on a cliff there is a golden chalice with a conic bowl, larger towards the rim and rounded at the base. The knob of the chalice is spherical, slightly flattened and the stem mimics a flower corolla opening towards the circular foot. We found corresponding characteristics on the chalice from Roandola ${ }^{27}$ published by Victor Roth in 1922.

The altarpiece devoted to The Holy Apostles sheltered by the Evangelic

${ }^{21}$ C. Firea, Arta polipticelor medievale, vol. II, p. 90.

${ }^{22}$ V. Roth, Kunstdenkmäler, p. 9, pl. 15/1.

${ }^{23}$ Ibidem, p. 11, pl. 17.

${ }^{24}$ Ibidem, pp. 87-88; V. Vătăşianu, Istoria artei feudale, p. 796; C. Firea, Arta polipticelor medievale, vol. II, p. 152.

${ }^{25}$ C. Firea, Arta polipticelor medievale, vol. II, p. 155.

${ }^{26}$ Maria Silvia Crăciun, "Polipticul de la Dupuş în contextul devoțiunii euharistice din Transilvania (sec. XV-XVI)”, in: Ars Transsilvaniae, XII-XIII, Cluj Napoca 2002-2003, p. 149.

${ }^{27}$ V. Roth, Kunstdenkmäler, p. 12, pl. 15/4. 
church in Hălchiu (Brașov County) has a painting owned to the renaissance artist Gregorius Pictor from Brașov ${ }^{28}$, who worked during the first half of the $16^{\text {th }}$ Century $^{29}$. The image of the chalice (plate 6) painted on the work-day side of the altarpiece is also connected with the Prayer on the Mount of Olives. The painting belonging to the "Danubian style"30, shows Jesus in prayer with his hands held up high to the sky and surrounded by the sleeping apostles. In front of him on a cliff there is a golden chalice with a flanged rim, a flattened node with vertical indents and a high stem supported by a probable circular foot. The shape resembles the preceding chalice above, having the same flanged rim and the same high stem flanged to form the foot.

An altarpiece repainted in a Baroque manner in $1715^{31}$ is the one in Tătârlaua (jud. Alba), but today after the $20^{\text {th }}$ Century restoration it can reveal the initial painting by Vincentius Pictor. In this case we know the sculptor (Simon Sculptor), the painter (Vincentius Pictor) and the date: 1508 (according to the inscription on the predella). ${ }^{32}$ On this medieval altarpiece we have identified four chalices, with similar features, two on the predella and two on the work-day side panels: the panel with the image of St. John the Baptist and St. John the Evangelist and the panel with St. Catherine and St. Barbara. The chalice in St. John the Evangelist's hand ${ }^{33}$ (plate 7a) is a liturgical golden vessel with a conic even bowl slightly rounded at the base, a pyramidal stem and circular high foot. The foot has a spherical indented node with four spherical buttons. The bowl is even and unornamented; the vertically indented node has the same spherical buttons, suggesting Romanesque or Early Gothic shapes. Quite similar with this item is the chalice held by St. Barbara, the painter probably using the same source as inspiration. The chalice with the floating Host (plate $7 \mathrm{~b}$ ) seems to be made out of the same type of precious metal and has the same bowl with a large flanged rim. The stem, the node and the foot are similar to those described above.

On the predella the two chalices collecting Christ's blood are held up by two angels, placed on each side of the wounded Jesus. We can trace some similarities with the central panel Vir dolorum Eucharistic in Brukenthal National Museum and dated approximately just one decade later. The chalices

\footnotetext{
${ }^{28}$ C. Firea, Arta polipticelor medievale, vol II, p. 166.

${ }^{29}$ Ibidem, vol I, p. 149.

${ }^{30}$ G. Richter, O. Richter, Siebenbürgische Flügelaltäre, pp. 221-222.

${ }^{31}$ C. Firea, Arta polipticelor medievale, vol. II, p. 182

32 Ibidem, p. 189.

${ }^{33}$ Thank you, once again, to Mr. Ciprian Firea for the information and photos (plate $7 \mathrm{a}, \mathrm{b}$, $8 \mathrm{a}, \mathrm{b}, 15,16)$ offered so kindly.
} 
depicted on the predella of Tătârlaua (plates $8 \mathrm{a}$ and $8 \mathrm{~b}$ ) have almost the characteristics with the other two, only their bowls having a more rounded base. This type of bowl, conical with no inscriptions on it shows similarities with the chalice from Buneşti (Braşov County). ${ }^{34}$ The node with the spherical buttons shows similarities with almost all the images included in this study.

An altarpiece devoted to The Virgin Mary and kept from the beginning in the Evangelic church of Mălâncrav is sheltered in one of the most beautiful parochial churches in Transylvania. The church possesses a vast mural ensemble realised in a "gothic linear-narration" manner and dated in the middle of the $14^{\text {th }}$ Century. ${ }^{35}$

Made under the patronage of the Apafi family in 1455-1465, the Marianic altarpiece still integral today, is one of the oldest and best preserved of such items. ${ }^{36}$ On the Feast-Day side, on Vierer, four martyr virgins are depicted, amongst them being St. Barbara holding her attributes: the tower and the chalice with the floating Host. The chalice (plate 9), depicted in a stylized manner, shows an even short bowl resembling the lower half of an egg. The faced stem is supported by a lobate foot segmented by three horizontal lines and the indented node has spherical buttons in relief.

The predella in the Evangelic church in Mediaș with the depiction of The Last Supper is dated in 1525-1530. ${ }^{37}$ Its benefactor and his coat of arms are depicted on the left side of the predella. In the scene of The Last Supper around the table there is the group of the Apostles; Jesus in the centre of the scene is holding the chalice in one hand, with the other offering the bread to Judas. The Renaissance painter, possibly Vincentius (the large number of paintings from this artist and the stylistic differences from one to another makes the identification of the unsigned but somewhat similar paintings challenging ${ }^{38}$ ), depicts the chalice (plate 10) in the same manner as the one on the predella in Jidvei: the foot is lobate, the node is quadrilobe, the bowl, and the high stem all resemble the image from Jidvei. The bowl is also even; on the median line it shows an ornamentation or bowl holder. One can easily notice the attention of the painter in depicting the details, the table of The

\footnotetext{
${ }^{34}$ V. Roth, Kunstdenkmäler, p. 15, pl. 18.

${ }^{35}$ Dana Jenei, Pictura murală gotică din Transilvania, București 2007, p. 72.

${ }^{36}$ V. Vătăşianu, Istoria artei feudale, pp. 777-778; C. Firea, Arta polipticelor medievale, vol. II, pp. 211-212.

${ }^{37}$ C. Firea, Arta polipticelor medievale, vol. II, p. 234.

38 A. Kertesz, "Un important monument de artă medievală la Cincu (jud. Brașov)", in: Cumidava, 12 (2/1989-1990), pp. 174-175; idem, "Altarele și sculptura", in: T. Nägler (ed.), 800 de ani, p. 71.
} 
Supper being full of vessels, metal ware and glassware.

The predella with the 14 Helping Saints initially placed in the Evangelic church in Moşna and sheltered today by the church in Cincu was dated in an inscription in 1521 and was signed by Vincentius Pictor ${ }^{39}$. The busts of the saints depicted on the predella are easy to spot against the neutral landscape of the background. In the central part St. Catherine and St. Barbara are depicted with their attributes: the wheel and the Eucharistic chalice with the Host. The chalice (plate 11) in St. Barbara's hands is massive with a big conical bowl having approximately the same diameter of the rim as the one of the foot. The stem has on its upper part a spherical indented node. The shape of this chalice is quite similar to the ones in Tătârlaua.

The polyptych altar sheltered in the Evangelic church in Sibiu and devoted to the Passion of Christ is divided in eight scenes. The ensemble is dated through two inscriptions: 1519 on the predella and 1545 on the central panel. ${ }^{40}$ In the lower part of the altarpiece with the Prayer on the Mount of Olives the Holy Apostles are depicted sleeping, while Jesus placed in the centre of the scene has his hands held up in prayer. In front of him on a green hill there is the chalice. The chalice (plate 12) seems made out of precious metal and has an even bowl with two lines on its lower part. They can indicate an engraved writing which often played an ornamental part on chalices as well. ${ }^{41}$ The short stem has on its upper part a node divided in four spherical buttons. The foot of the chalice is high and lobate. The shapes of the bowl, node and foot show similarities with the chalice depicted on the panel devoted to St. Barbara Martyr (plate 17).

A fragmentary altarpiece currently in the possession of Brukenthal National Museum and dating from the first quarter of the $16^{\text {th }}$ Century shows the image of two saints often depicted on such items: St. Catherine and St. Barbara with their attributes. ${ }^{42}$ Although on the piece in the museum only St. Catherine is depicted on the right side, one can observe the attribute of St. Barbara - the Eucharistic chalice. The tall chalice (plate 13) has a conical elegant bowl slightly rounded in its lower part with flanged (possibly

\footnotetext{
${ }^{39}$ G. Richter, O. Richter, Siebenbürgische Flügelaltäre, pp. 240-247; C. Firea, Arta polipticelor medievale, vol. II, p. 239.

${ }^{40}$ I. Albu, Inschriften der Stadt Hermannstadt, Sibiu 2002, nr. 28; p. 36; C. Firea, Arta polipticelor medievale, vol. II, p. 299.

${ }^{41}$ Once again I express my thanks to Ms Daniela Dâmboiu for the information offered so kindly.

${ }^{42}$ V. Roth, Siebenbürgische Altäre, Strassburg 1916, p. 182; E. Nagy-Sarkadi, Local Workshops, p. 215 .
} 
quadrilobe) rim. A divided node is placed on the stem on which a vegetal motif goes down to the lobate foot. The shape resembles the chalice in Sântioana (Mureș County). ${ }^{43}$

The altarpiece of the parochial church in Șaeș, now displayed in the Evangelic church "on the Hill” in Sighișoara, has on its upper side a semicircular lunette on which Saints Apolonia, Catherine and Barbara are depicted. ${ }^{44}$ The painting has Renaissance influences and can be dated to $1520-1525 .{ }^{45}$ The chalice as the attribute of St. Barbara is also depicted here (plate 14). This time the saint holds the vessel in her left hand and the Host in her right (common traits with the painting in Tătârlaua). The popularity of St. Barbara in preReformation Transylvania is proved by the large number of paintings of her on the panels. At the time she was included in the five Virgines capitals. ${ }^{46}$ The chalice depicted on the altarpiece from Șaeș has a bowl with a large flanged rim, its holder being suggested by a line of a darker tone. The stem is flanged in a circular foot and has a spherical vertical divided node. The predella of the altarpiece also has a depiction of a chalice in the painting of the Prayer on the Mount of Olives (The Passion of Christ cycle).

The altarpiece from Leliceni (Harghita County), dated according to the inscription on the predella in 1510, is today sheltered by the Hungarian National Gallery in Budapest. ${ }^{47}$ On the fixed and mobile panels eight scenes are depicted, all parts of the cycle The Passion of Christ. One of the panels shows Jesus in prayer near the sleeping apostles. On a cliff in front of him a chalice is depicted (plate 15). It has a conical bowl, a high stem with a node and a lobate foot. The bowl, the high stem and the lobate foot show similar features with the chalice from Zagăr (Mureş County). ${ }^{48}$

Another image of St. Barbara with her attributes (the chalice with the floating Host and the tower) is depicted on a panel with St. Ana with Mary and Jesus from the Catholic church in Vlaha now in the collections of the

\footnotetext{
${ }^{43}$ V. Roth, Kunstdenkmäler, pl. 20/1.

${ }^{44}$ V. Roth, Siebenbürgische Altäre, p. 110; V. Vătășianu, Istoria artei feudale, pp. 790, 794; C. Firea, Arta polipticelor medievale, vol. II, p. 363.

${ }^{45}$ V. Vătășianu, Istoria artei feudale, p. 791; C. Firea, Arta polipticelor medievale, vol. II, p. 356.

${ }^{46}$ D. Dâmboiu, "Reprezentări iconografice ale Sfintei Barbara", in: B. A. M., IV, 2, Sibiu 2009, p. 297.

${ }^{47}$ V. Vătăşianu, Istoria artei feudale, p. 786; C. Firea, Arta polipticelor medievale, vol. II, p. 199.

${ }^{48}$ V. Roth, Kunstdenkmäler, pl. 19.
} 
Batthyaneum Library in Alba Iulia. ${ }^{49}$ The panel dated in $1515-1520^{50}$ has small dimensions and was almost certainly placed on one of the lateral altars of the church. On its left upper volet St. Barbara is holding in her right hand the chalice with the Host (plate 16). The item was carefully depicted. The chalice has an even bowl with flanged rim. The holder of the bowl is well detailed, with decorations suggesting filigree work. The faced stem with no ornamentation stands on a high lobate foot. It has a quadrilobate node. A possible similarity for the bowl and the stem might be the chalice in Fişer (Brașov County)..$^{51}$

A panel of unknown origin with the image of St. Barbara's Martyrdom is to be found today in Brukenthal National Museum in Sibiu. It dates back to $1480-1490 . .^{52}$ The saint is opposed to the worldly image of the tormentor. The painting displays again the saint's attributes. The tower in which she was captive and the golden chalice with the floating Host and Agnus dei are depicted on the right side of the kneeling saint facing the observer.

The early gothic chalice with Romanesque traces (plate 17) takes its beauty from its simple silhouette. The even bowl shows no ornaments. On the pyramidal stem flanged in a lobate foot a node is placed ${ }^{53}$, divided in four spherical buttons. As the researcher Daniela Dâmboiu noticed we can find this type of node together with the polylobate foot on several other Transylvanian chalices: Zagăr, Sântioana, Vinda. ${ }^{54}$

Another panel of unknown origin themed Vir Dolorum Eucharistic is to be found in the collections of the same museum. It is a well done painting dating from $1515-1520^{55}$ or $1525^{56}$, realised in tempera on wood support, unfortunately in a poorly conserved condition. Jesus is holding a Host in his right hand. At his feet there is a richly ornamented golden chalice. Christ crowned in thorns is supported by two angels, the Host in his hand and the chalice at his feet being direct symbolic suggestions to the transubstantiation

\footnotetext{
${ }^{49}$ V. Roth, Siebenbürgische Altäre, pp. 30-31; V. Vătășianu, Istoria artei feudale, p. 788; C. Firea, Arta polipticelor medievale, vol. II, pp. 387-388.

${ }^{50}$ V. Vătășianu, Istoria artei feudale, p. 788; C. Firea, Arta polipticelor medievale, vol. II, p. 387.

${ }^{51}$ V. Roth, Kunstdenkmäler, pl. 108/2.

${ }^{52}$ C. Firea, Arta polipticelor medievale, vol. II, p. 330.

${ }^{53}$ D. Dâmboiu, Bresla aurarilor, p. 70.

${ }^{54}$ Ibidem.

${ }^{55}$ C. Firea, Arta polipticelor medievale, vol. II, p. 311.

${ }^{56}$ A. Kertesz, "Altarele și sculptura”, p. 77.
} 
dogma and to the Eucharistic celebration with each Liturgy. ${ }^{57}$ The carefully depicted golden chalice (plate 18) has a big even bowl with a slightly flanged rim and holder with vegetal decorations suggesting an enamel filigree work. The node is vertically divided and the stem seemingly made out of several twisted bands is supported by a foot which due to the degradation of the painting cannot be described but was most likely lobate according to the stylistic evolution of the chalice at the time.

The altarpiece in Dupuș (Sibiu County) is today sheltered for safekipping by the Evangelic church in Mediaș. It is dated back to 1475-1485 and was altered, probably after it was bought by the priest in Dupus, the predella and the corpus not belonging to the ensemble. ${ }^{59}$ In the cycle The Passion of Christ depicted on the work-day side we also find the Prayer on the Mount of Olives. Jesus is painted in prayer with the chalice in front of him on a rock. The chalice (plate 19) has an even bowl, a quadrilobate node, a short stem and a circular foot with a vertical cut rim.

The last image of this study is depicted on the altarpiece of the church in Șoroștin (since 2002 sheltered in the sacristy of the Evangelic church in Mediaş). Here in the same scenes of The Passion of Christ on the volet with the Prayer on the Mount of Olives and in front of the praying Christ there is the image of the chalice (plate 20). The chalice with Romanesque influences has an even bowl with no ornamentation, a pyramidal stem and a lobate foot. The node is a slightly flattened sphere also divided. ${ }^{60}$ It shows similarities with the chalices from Zagăr, Sântioana and Vinda.

The image of the chalice is to be found on other altarpieces as well (Şmig, Jimbor, Biertan) and also in mural paintings (such as the northern wall of the nave-church in Cricău, on the apse of the church in Mălâncrav, in the churches from Brateiu, Alțâna, Mediaş, etc.).

One of the most popular transpositions of the biblical text in the paintings of the Transylvanian altarpieces is the Prayer in the Garden of Gethsemane, which opens the cycle of The Passion of Christ. The place was situated east from Jerusalem on the western slope of the Mount of Olives. Here, according to St. Matthew's Gospel, "Then Jesus went with them to a place called Gethsemane" (Matthew, 26:36) and there "And going a little farther, he threw himself on the ground and prayed, 'My Father, if it is possible, let this cup

\footnotetext{
${ }^{57}$ V. Roth, Siebenbürgische Altäre, p. 182.

${ }^{58}$ C. Firea, Arta polipticelor medievale, vol. II, p. 131.

${ }^{59}$ Ibidem, pp. 133-134.

${ }^{60}$ D. Dâmboiu, Bresla aurarilor, p. 70.
} 
pass from me; yet not what I want but what you want." (Matthew, 26:39).

We also often find the image of the chalice as the attribute of St. Barbara, a martyr of the $3^{\text {rd }}$ Century and worship both by the western and eastern Christianity. She is the protector against sudden death without the last sacraments and can be recognised in paintings by her attributes: the tower and the chalice (sometimes with a Host). After the adoption of Reformation the Eucharistic ritual became a commemorative act of The Last Supper. ${ }^{61}$ The chalice was gradually replaced by the Communion beaker or jug. Starting with that moment in the Protestant cult a part of the profane vessels would be used as liturgical vessels. ${ }^{62}$

One conclusion is that the chalice, being one of the most important items amongst the sacred vessels used during liturgy, is often depicted in Ecclesiastical painting and is a genuinely ichnographical document. The thorough research of mural and panel painting depicting pieces of material life set against the real items still surviving in collections or elsewhere can be a source for documenting medieval material culture. The development of these arts in workshops, certified by the numerous notes on local craftsmen, is a result of the demand for cult vessels to be used during Christian services. The existence of the paten and the chalice during liturgy is necessary while the priest utters the consecration words. A sacral object, necessary to hold the substance which will transubstantiate into the blood of Jesus, the chalice is often depicted with the Host (see plates 5a, 9, 11, 16, 17), a suggestion of the doctrine of concomitance. The occurrence of this sacral vessel on almost half of the altarpieces in Transylvania shows its importance in the religious services but also documents a highly spread craft in medieval Transylvania - liturgical silverwork.

Concerning the authenticity of the chalices depicted on Transylvanian altarpieces, the items still existing in museum collections certify a local source of inspiration. There are no perfect similarities between the images and the real items, the images being often of a stylised manner, but they all show similar features as a result of the style of the time when they were made / painted. Even if the painted altarpieces belong to the $15^{\text {th }}-16^{\text {th }}$ centuries, the image of the chalice show traces of Romanesque reflected in the small conical shapes of the bowl with rounded bases, in the stem and foot treated as an unity, in the divided slightly flattened spherical shape of the node and in the

${ }^{61}$ I. Albu, "Destinația liturgică și simbolică obiectelor de altar", in: T. Nägler (ed.), 800 de ani, p. 101.

${ }^{62}$ Ibidem, pp. 84-85. 
vertically cut rim of the foot. ${ }^{63}$ Starting with the $15^{\text {th }}$ century, the shape of the chalice slightly alters, the foot becoming polilobate, the stem pyramidal and the buttons on the node being more preeminent. In the middle of the $15^{\text {th }}$ century, during the extension of constructing sites, the fortification and the altering of the architectural elements, the inside furniture changes as well. The chalice receives also gothic ornamentation, the node adopting the specific shapes $^{64}$ and the holder of the bowl now having engraved ornamentation ${ }^{65}$.

Some of these features are also traceable in the paintings, although as we have previously shown there is an obvious time lag between the image of the item and the item itself when manufactured by silversmiths.

\section{List of illustrations:}

1. The altarpiece devoted to St. Ursula from the Evangelic church in Beia (Braşov County)

2. The altarpiece devoted to St. Nicolae from the Evangelic church in Bruiu (Sibiu County) (apud Emese 2012)

3. The altarpiece devoted to St. Nicolae from the Evangelic church in Cund (Mureş County)

4. The altarpiece devoted to St. Sfintei Fecioare from the church in Cetățuia (Harghita County)

5. ( $\mathrm{a}$ and b) The altarpiece devoted to St. Martin from the Evangelic church in Fişer (Braşov County)

6. The altarpiece devoted to The Holy Apostles from the Evangelic church in Hălchiu (Braşov County)

7. The altarpiece devoted to The Virgin and Saints from the Evangelic church in Tătârlaua (Alba County)

8. ( $\mathrm{a}$ and $\mathrm{b}$ ) The predella of the altarpiece devoted to The Virgin and Saints from the Evangelic church in Tătârlaua (Alba County)

9. The altarpiece devoted to The Virgin from the Evangelic church in Mălâncrav (Sibiu)

10. The painted predella with The Last Supper from the Evangelic church in Mediaş (Sibiu County)

${ }^{63}$ D. Dâmboiu, Bresla aurarilor, pp. 62, 70.

${ }^{64}$ Corina Nicolescu, Arta metalelor prețioase în România, București 1973, p. 28.

${ }^{65}$ Ibidem, p. 66. 
11. The predella with The 14 Helping Saints from the Evangelic church in Moşna (Sibiu County)

12. The altarpiece devoted to The Passion of Christ from the Evangelic church in Sibiu

13. The altarpiece devoted to The Saints in the collection of Brukenthal National Museum Sibiu (Sibiu County)

14. The lunette of an altarpiece with St. Apolonia, Ecaterina and Barbara from the Evangelic church in Şaeş (Mureş County)

15. The altarpiece with the Descent of the Holy Ghost from the church Leliceni (Harghita County)

16. The altarpiece with St. Ana from the Catholic church in Vlaha (Cluj County)

17. Panel of an altarpiece with St. Barbara Martyr in Brukenthal National Museum Sibiu

18. Central panel with Vir Dolorum Eucharistic, in Brukenthal National Museum Sibiu

19. The altarpiece from the Evangelic church in Dupuş (Sibiu County)

20. The altarpiece devoted to The Birth and Passion of Christ from the Evangelic church in Şoroştin (Sibiu County)

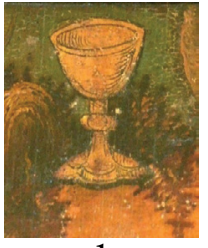

1

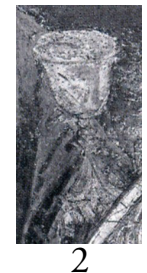

2

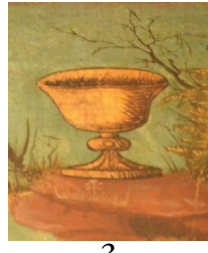

3

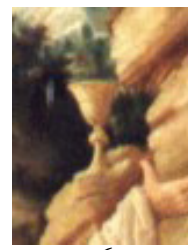

6

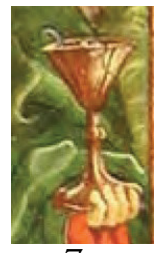

$7 \mathrm{a}$

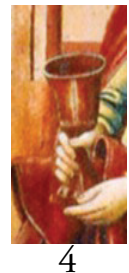

4

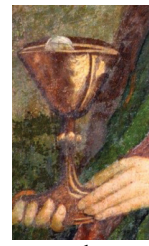

$7 b$

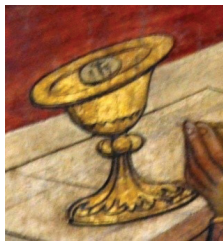

$5 a$

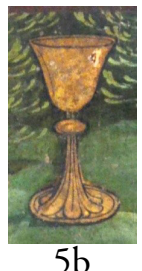

$5 b$ 
Images of Chalices in Transylvanian Panel Paintings

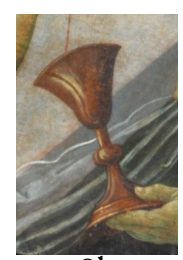

$8 \mathrm{~b}$
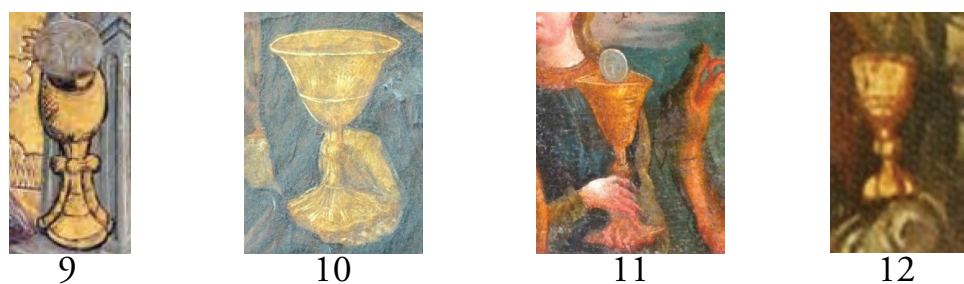

12

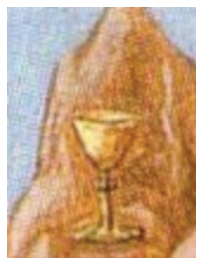

15

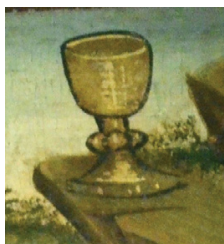

19
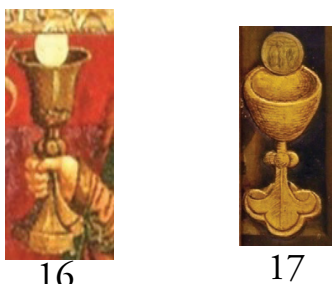

17

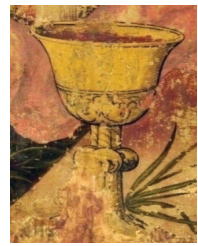

18

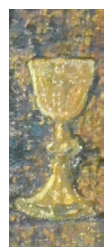

20 